\title{
La adaptación de la fiscalidad aduanera a los intereses repobladores, comerciales y políticos. Andalucía, 1241-1550*
}

\author{
José Damián González Arce ${ }^{1}$ \\ Universidad de Murcia \\ josedam@um.es
}

RESUMEN: El presente trabajo tiene por objetivo analizar la política regia de exenciones y reducciones del almojarifazgo aduanero en las tierras andaluzas durante la baja Edad Media; que generalmente afectaban, además, a otros derechos de paso, como el portazgo, similar al demandarse también por la entrada y salida de las poblaciones, el diezmo y medio diezmo de lo morisco, en este caso sobre las importaciones y exportaciones con Granada, y otros marginales, como rodas, castillerías, peajes... La concesión de estas franquezas nos desvela cuáles eran los intereses económicos y políticos de los monarcas en cada período y coyuntura. Mientras que su reducción o supresión ponen de manifiesto los cambios habidos con el tiempo, que hicieron desaparecer o disminuir las causas de la despoblación, inseguridad fronteriza o atraso económico que habían motivado las exoneraciones. Para ello ha sido utilizada la documentación fiscal conservada en el Archivo General de Simancas, así como en los municipales de Sevilla, Córdoba, Carmona o Jerez. Finalmente, se concluye que tales ventajas sirvieron a un propósito repoblador y que solo las poblaciones más expuestas o estratégicas fueron capaces de mante-

* Este artículo ha sido realizado en el marco de los proyectos HAR2013-45788-C4-1-P «El Negocio de la Fiscalidad»: arrendamientos, gestión fiscal y deuda pública (fines siglo XV1556), y HAR2014-52469-C3-1-P, Poder, fiscalidad y sociedades fronterizas en la Corona de Castilla al sur del Tajo. Siglos XIV-XVI, ambos del Ministerio de Economía y Competitividad e integrados en la red Arca Comunis.

Archivo General de Simancas (AGS); Archivo Histórico Nacional, Sección Nobleza (AHN-SN); Archivo Histórico Provincial de Sevilla (AHPS); Archivo Municipal de Carmona (AMCa); Archivo Municipal de Córdoba (AMCo); Archivo Municipal de Jerez de la Frontera (AMJF) y Archivo Municipal de Sevilla (AMS).

1 ORCID iD: https://orcid.org/0000-0002-3296-0554. 
nerlas más o menos intactas con el paso de los años, sobre todo cuando eran además puntos clave para el comercio exterior.

PALABRAS CLAVE: fiscalidad; impuestos; aduanas; comercio; exenciones; privilegios.

The alignment of customs duties to the interests of settlers, commerce and politics. Andalusia, 1241-1550

ABSTRACT: This paper aims to analyze the royal policy of exemptions and reductions of customs duties in Andalusia during the Late Middle Ages. In particular, the taxes studied are the almojarifazgo, tithes, the Moorish half-tithe imposed on imports and exports with Granada, and other marginal taxes, such as rodas, castillerías and tolls. The granting of these franchises reveals the economic and political interests of monarchs in particular periods and circumstances. Their reduction or elimination, on the other hand, shows the changes over time that removed or reduced the causes of depopulation, border insecurity and economic backwardness that motivated the exemptions. The documentation used is from the Archivo General de Simancas and the municipal archives of Seville, Cordoba, Carmona and Jerez. Finally, we conclude that tax advantages served to attract population, and that only the most exposed or strategic populations were able to remain more or less intact over time, especially when they were also key elements for foreign trade.

KEY WORDS: $\quad$ taxation; tax; customs; trade; exemptions; privileges.

CÓMO CITAR ESTE ARTÍCULO/CITATION: González Arce, José Damián, «La adaptación de la fiscalidad aduanera a los intereses repobladores, comerciales y políticos. Andalucía, 1241-1550», Hispania, 78/258 (Madrid, 2018): 39-67. https://doi.org/103989/ hispania.2018.002.

\section{INTRODUCCIÓN}

El objetivo de este trabajo es realizar un primer estudio de conjunto de la política arancelaria seguida por las autoridades territoriales — principalmente de la Corona castellana, pero también por parte de los señores solariegos y los concejos-, en Andalucía, desde tiempos de la conquista cristiana, a mediados del siglo XIII, hasta el reinado de Carlos I, a mediados del XVI. Se trata de analizar la serie de mercedes, exenciones o reducciones en los impuestos aduaneros y sobre el tráfico comercial, fundamentalmente el almojarifazgo, pero también otros similares como el portazgo y los peajes, concedidos a las diferentes poblaciones y a sus habitantes. Compararlas entre ellas, ver cómo, por qué, por quién, para quién y en qué medida fueron concedidas; cómo se transmitieron, o se inspiraron, de unos lugares a otros; la forma en la que evo- 
lucionaron a lo largo del tiempo; su vigencia y su observancia; y, finalmente, cómo, y por qué, fueron alteradas, reducidas y, a veces, suprimidas.

Para ello, al tratarse de un ensayo sobre los tributos aduaneros relativos tanto al comercio exterior — sobre todo marítimo, pero también terrestre con la Granada nazarí-, como interior - entre reinos castellanos o entre diferentes concejos dentro de una misma jurisdicción fiscal territorial-, y su adaptación a la realidad y necesidades repobladoras, el análisis pivotará en torno al almojarifazgo; por lo que el espacio geográfico que se va a tratar es el de la Andalucía costera, tanto atlántica como mediterránea, las grandes capitales con las principales aduanas, donde era recaudado dicho impuesto, y los territorios fronterizos con el reino granadino.

Las fuentes manejadas para tal fin son la extensa documentación conservada en el Archivo General de Simancas, fundamentalmente para los privilegios de exención concedidos a las distintas localidades, y su transformación en el tiempo; los pleitos de las Chancillerías de Valladolid y Granada, sobre la observancia y vigencia de dichos privilegios; y los archivos concejiles (Sevilla, Córdoba, Carmona, Jerez de la Frontera y otros), sobre todo su actas capitulares, pero también los diplomas originales con los textos de las mercedes y demás expedientes, donde se aprecia cómo fueron llevadas a cabo éstas y los conflictos a que dicha aplicación dio lugar, tanto con los agentes fiscales de la Corona, como con los de los señoríos y concejos vecinos. Se trata de una documentación fragmentaria e inconexa, por lo que no siempre es posible reconstruir con los textos que se han conservado los procesos de concesión de franquezas, sus motivaciones y cómo cambiaron con el tiempo, en función de los ciclos económicos o las coyunturas políticas. Sin embargo, gracias a los numerosos pleitos que los beneficiarios de dichas gracias emprendieron, a veces en fechas tan tardías como mediados del siglo XVI, para que les fuesen respetadas, entre cuyas páginas se solían copiar los privilegios que recibieron a lo largo de los años, ha sido posible reconstruir un panorama de cómo fue la presión fiscal aduanera en la mitad sur andaluza durante más de tres siglos, a qué intereses comerciales y políticos atendió, y cómo evolucionó.

Con este objetivo, se ha partido de estudios previos relativos a la tributación arancelaria, caso sobre todo de la extensa obra del profesor Ladero Quesada $^{2}$, así como de algunos regionales ${ }^{3}$. También han sido de gran utilidad los

2 Este autor es el que más extensamente ha tratado la fiscalidad medieval castellana. En sus obras generales se recogen imprescindibles apartados sobre los tributos arancelarios y aduaneros: LADERO: 1973a: 95-150; 1993: 131-173; 2009: 91-148. También ha dedicado otras específicamente al almojarifazgo: LADERO, 2 (Madrid, 1969); o a las aduanas castellanas: LADERO, 7 (Ginebra, 1973b).

3 GARCÍA HERRERO, 4 (Madrid, 1984). MARTÍNEZ, 1987. MENJOT, 1987. OTUÑO, 8 (Yecla, 1997). 
trabajos del profesor Collantes de Terán sobre las exacciones indirectas andaluzas en general, y sevillanas en particular ${ }^{4}$.

\section{EXENCIONES Y ESTRATEGIAS REPOBLADORAS EN EL SIGLO XIII}

Las primeras libertades sobre la circulación de mercancías se comprenden en los fueros. El de Córdoba, derivado del toledano y redactado el año 1241, dispone que sus caballeros gozarían de los mismos privilegios y franquezas que los de la ciudad manchega; esto es, exención de portazgo para los caballos y mulas que comprasen, así como para los intercambios de moros por cautivos cristianos. Además, todos los vecinos y moradores cordobeses, según su fuero, quedaron redimidos del pago de portazgo en la localidad y su término municipal. Tampoco debían abonarlo por la caza y pesca de los ríos, es de suponer, por tanto, que se refiere a los artículos traídos de fuera del alfoz. Esta franquicia fue aumentada posteriormente por Sancho IV, que les suprimió el pago de portazgo y alcabala en todo el reino. Sin embargo, no resultó respetada posteriormente por los almojarifes y portazgueros, en especial de Toledo y Sevilla, que alegaban que la merced solo afectaba a los bienes producidos en la misma Córdoba, llevados a vender fuera, o a los adquiridos para ser allí introducidos. Tras la protesta del concejo cordobés, Fernando IV ratificó en 1296 el privilegio de su padre y dio a entender que los habitantes estaban libres de pagar derechos de todos los artículos que transportasen por todo el reino; excepcional concesión que no tardaría en verse recortada, como ocurrió con las dadas a otras poblaciones. No obstante, todavía en una confirmación de Alfonso XI de 1314 se mandó actuar como se venía haciendo desde tiempos de su abuelo, el citado rey Sancho. El cual, además, en 1284 había otorgado a la ciudad dos ferias anuales libres de portazgo 5 .

Sevilla, mucho más atractiva que Córdoba para los repobladores, no fue, por tanto, tan privilegiada tras su conquista. De forma que su fuero, dado por Fernando III en 1251, a pesar de que también provenía del toledano, no contemplaba la exención de portazgo, si bien sus caballeros, como los cordobeses, recibieron las libertades de los manchegos. Dos años más tarde, en 1253, Alfonso X aprovechaba la confirmación del fuero para recortar algo los tributos comerciales comprendidos en el almojarifazgo local. Caso de algunas ta-

4 Además de los citados más adelante, cabe destacar: COLLANTES, 1997; 1999; 2006; 2014.

5 AMCo, caja 1, 10 y 21. GONZÁLEZ ARCE, 17 (Granada, 1992): 409; 61 (Toledo, 2005): 60. BENAVIDES, 1860, vol. 2: 109-110. Para un análisis general sobre las políticas regias en materia comercial y de reducción de las cargas aduaneras en Castilla, PORRAS, 15 (Madrid, 1992).

Hispania, 2018, vol. LXXVIII, nº 258, enero-abril, págs. 39-67, ISSN: 0018-2141, e-ISSN: 1988-8368 https://doi.org/10.3989/hispania.2018.002 
sas exigidas a los barcos que iban y venían a Córdoba o Jerez; el portazgo de las gallinas, huevos, ánsares, lechones... traídos de fuera del reino de Sevilla; y el de la madera, pez, estopa, cáñamo o plomo. Más adelante, en 1256, por fin franqueó a los sevillanos del pago de este impuesto por sus mercancías y en la propia ciudad. En 1297 la capital hispalense vio ampliada esta redención inicial a toda suerte de gravámenes de compraventa y tránsito, y en toda Castilla, por parte de Fernando IV. Merced excepcional que hubo de ser renovada en 1304, porque no era observada por los portazgueros y almojarifes. En 1326, Alfonso XI, una vez proclamado mayor de edad, tuvo que volver a ratificar este privilegio y especificar que los vecinos también estaban redimidos del pago de alcabalas, en especial la de las bestias, que tampoco habían de abonar los cordobeses y jerezanos. Se trató de años conflictivos plagados de guerras y gobiernos interinos, debido a la sucesión de minorías de edad y regencias, en los que los recaudadores hacían poco caso a las exenciones ${ }^{6}$.

Desde tiempos de los califas ortodoxos, en el imperio islámico se percibía el diezmo por las mercancías importadas y exportadas desde o hacia territorios extranjeros ${ }^{7}$. Este canon del $10 \%$, similar por tanto al exigido sobre las cosechas y ganados, sería el que encontraron los reyes cristianos cuando conquistaron las diferentes taifas andalusíes, a partir de la caída del reino de Toledo (1085); pues habría sido el que los emires musulmanes recaudarían sobre el comercio exterior, aunque se realizase con otros emiratos, y que ahora pasó a ser cobrado por la hacienda real castellana, que mantuvo el statu quo previo y siguió demandando aranceles por el tránsito de artículos mercantiles entre los nuevos reinos incorporados, y entre éstos y el resto de la Corona. Dicha exacción acabó por ser denominada, como sabemos, «almojarifazgo». Debido, entre otros motivos, a que como ocurrió en primer lugar en el reino de Murcia, y luego en otras partes, el gravamen aduanero vio reducida su tarifa del 10\% inicial a tasas inferiores, para así fomentar la repoblación de los territorios recientemente anexados a la Corona; de forma que no pudo mantener su apelativo de «diezmo» ${ }^{8}$.

De este modo, en Sevilla, por su mayor atractivo y desarrollo económico menos privilegiada que Murcia, donde el tipo era de solo el 5\%, el gravamen general del almojarifazgo hispalense se mantuvo durante los siglos XIII-XV en el mencionado $10 \%$, tal y como reflejan los manuales florentinos de mercadería de la decimocuarta centuria y según se recoge en el padrón de 1491,

6 GONZÁLEZ ARCE, 10 (Salamanca, 1992): 78-79; 15 (Salamanca, 1997): 247; 2003: 144-145, 152-153 y 159-160. GONZÁLEZ JIMÉNEZ, 1991: 189-190. FERNÁNDEZ, OSTOS y PARDO, 1993: 251-252, 257-260 y 283-284. COLLANTES DE TERÁN, 41 (Sevilla, 2013): 299-300.

7 ABBOUD-HAGGAR, 31 (Madrid, 2008): 498.

8 GONZÁLEZ ARCE, 42/2 (Barcelona, 2012): 670-671. 
el único conocido. En el que a los comerciantes del resto de Castilla o de territorios aliados, como Génova, se les rebajó como merced al 5\% ${ }^{9}$. Aunque estas salvedades fueron tan numerosas que han dado lugar a confusiones, y a hacer pensar todo lo contrario, que el arancel general era del 5\% y excepcionalmente se pagaba una tasa del 10 .

En consecuencia, ha de entenderse que cuando Alfonso X franqueó a los sevillanos del pago de diezmo por los higos, aceite y otros frutos de sus tierras exportados fuera del reino, lo que encerraba esa franqueza era la anulación del $10 \%$ en concepto de almojarifazgo. Sabemos de esta merced porque en 1272 los vecinos se quejaron al monarca de que, si bien no se les reclamaba el tributo a la salida de las mercancías, sí se hacía con las de retorno, compradas con el dinero de la venta de las primeras. Lo que conducía a que no gozasen de mejor trato que los forasteros, que únicamente abonaban un «diezmo» (sic), bien por la salida o bien por la entrada, con la vuelta exenta, por tanto. De manera que el rey dispuso que no se exigiese derecho alguno por los retornos de los sevillanos. Según las ordenanzas del siglo $\mathrm{XV}$, tanto los vecinos como los demás moradores de Sevilla que allí llevasen paños y otros artículos por mar debían tributar de entrada la veintena (5\%), y de salida la cuarentena (2,5\%), y tendrían libre la saca de las mercancías de retorno. El comercio de importación y exportación con Granda quedó gravado para todos con el $10 \%$, o diezmo de lo morisco, excepto el aceite que ya abonaba el diezmo del Aljarfe u otros específicos ${ }^{10}$.

Además, como he dicho más arriba, en el comercio hispalense se concedieron reducciones a otros colectivos mercantiles o a determinados productos. Entre los siglos XIII y XV los reyes castellanos otorgaron a la colonia genovesa asentada en Castilla en general, y a la sevillana en especial, una gran cantidad de ventajas en materia fiscal para potenciar su tráfico mercantil, lo que la convirtió en su principal aliada en este ámbito. En el privilegio fundacional del consulado de los genoveses de Sevilla, de 1251, se dispuso que cuando fuesen camino de su tierra no debían satisfacer tributo alguno si no arribaban a puertos castellanos bajo control cristiano, esto es, si lo hacían a surgideros sitos en territorios bajo domino musulmán en tierras de protectorado castellano. Si llegaban a fondeaderos cristianos y vendían sus mercancías

9 GONZÁLEZ ARCE, 15 (Salamanca, 1997): 247-254. GONZÁLEZ ARÉVALO, 38 (Sevilla, 2011): 224. Para una copia del arancel, ORDENANZAS DE SEVILLA, 1632, fols. 56v-61r.

10 GONZÁLEZ ARCE, 2003: 170-171. ORDENANZAS DE SEVILLA, 1632, fol. 64r-v. Los habitantes de Sevilla estaban exentos desde el reinado de Juan I del pago de esta exacción por los artículos allí llevados desde Granada, LADERO QUESADA, 2 (Madrid, 1969): 99. Los tipos impositivos de Córdoba serían los mismos que en Sevilla, 10, 5 y 2,5\%, GONZÁLEZ ARCE, 37 (Madrid, 2014c): 186. 
estaban sujetos al pago de impuestos; si no las vendían debían abonar los gravámenes a los que todos estaban obligados por las cartas forales. En caso de ser conquistadas nuevas tierras costeras no sujetas a régimen de protectorado, las imposiciones a pagar en ellas serían las mismas que las exigidas en Sevilla. Los sucesores de Fernando III no podrían demandar mayores gabelas que las fijadas en este privilegio, que para las mercancías importadas por los ligures, y vendidas en Sevilla, se situaron en el 5\% en concepto de almojarifazgo. Si lo que se introducía era dinero en metálico, entonces la exacción sería del 2,5\% por lo comprado con él, es de suponer que con destino a la exportación. Mismos cánones que los vistos en Murcia. Por el aceite adquirido con dinero debían, además, pagar una tasa de 1 meaja de plata, de la moneda sevillana, por cada jarra. Aquellas mercancías metidas en la ciudad pero no vendidas podían ser sacadas sin dar derecho alguno; sin embargo, si se llevaba trigo o vino no se podía luego reexportar. En 1281 los cónsules ligures denunciaron ante Alfonso X que había continuos enfrentamientos entre sus representados y los recaudadores del almojarifazgo, debido a que éstos no respetaban sus franquezas. El rey dispuso que los genoveses abonasen de arancel de entrada la tasa ya vista del 5\%, mientras que quedaban exentos de pagar por la exportación de las cosas que llevasen de retorno, compradas con lo obtenido por la venta de las importadas. A excepción del aceite adquirido en Sevilla, del cual debían tributar 2,5 onzas de plata fina por cada 100 jarras, a razón de un marco por cada 320; por la compra de menos de 100, tenían que entregar 1 meaja por jarra de la moneda que circulase en la ciudad, como estaba fijado por Fernando III. Por lo que respecta al dinero amonedado, también se renovó el canon fernandino del 2,5\%, jurando los exportadores que no habían comprado las mercancías con numerario obtenido de la importación fraudulenta de otros artículos $^{11}$.

Las mercedes conseguidas por los ligures en el siglo XIII se extendieron a otras comunidades mercantiles en Sevilla, que también recibieron un trato preferente por ser igualmente socios estratégicos en la política comercial de la Corona, caso de los catalanes, en el año 1281, y los bayoneses. Mientras que algunas localidades costeras vascas, entre ellas San Sebastián y Guetaria, fueron premiadas en la primera mitad del siglo XIV con las mismas reducciones de las que gozaban las antedichas naciones, como recompensa a la ayuda naval prestada en la toma de diversas plazas andaluzas, sobre todo Algeciras ${ }^{12}$.

11 GONZÁLEZ ARCE, 28 (Salamanca, 2010): 195-196.

12 En 1282 los catalanes fueron autorizados durante 3 años a sacar cualquier mercancía no vedada sin pagar almojarifazgo por el mismo importe del cereal que introdujesen en Sevilla GONZÁLEZ ARCE, 21 (Madrid, 2011): 87. GONZÁLEZ JIMÉNEZ, 1991: 514-515, 520, 522-524 y 536-537. 
La exención de portazgo para los vecinos de Carmona y en la propia villa, así como de la pesca y géneros obtenidos en el monte, aparece contenida ya en su fuero, dado por Fernando III en 1252. En 1256 Alfonso X volvió a conceder a los residentes franqueza de portazgo por los productos de su cosecha en la localidad. Como en los casos anteriores, Fernando IV mejoró estas franquicias y en 1303 los redimió de pagar portazgo, y otros derechos de tránsito -almojarifazgo implícitamente, pues-, por toda suerte de mercancías en toda Castilla, excepto Sevilla, Toledo y Murcia ${ }^{13}$.

Jerez de la Frontera obtuvo el fuero de Sevilla en 1268, y con él sus libertades en materia comercial. Tal y como consta en un privilegio de Sancho IV de 1285 y en otro de confirmación de Fernando IV, de 1308, en el que este rey recordaba que los vecinos eran francos de cuanto comprasen o vendiesen, llevasen o trajesen, de pagar diezmo, portazgo y otros derechos ${ }^{14}$.

Arcos de la Frontera, Niebla, Huelva, Gibraleón, Palos de la Frontera, Medina Sidonia, Gibraltar, Alcalá de los Gazules, Tarifa, Osuna y Morón de la Frontera anduvieron caminos paralelos al visto de Jerez en materia de exenciones, también por ser localidades fronterizas o costeras que, por los riesgos que corrían, debieron ser más privilegiadas con el fin de que no se despoblasen. Con las franquezas sevillanas, en 1263 Niebla obtuvo exención de portazgo en toda Castilla, excepto en Sevilla, Toledo y Murcia, para las mercancías llevadas para su abastecimiento; privilegio confirmado en 1267 y ampliado en la ratificación de Fernando IV, de 1299, a cualquier otro derecho de tránsito. Del portazgo también estuvieron libres sus antiguas villas de Huelva y Gibraleón, aforadas según la localidad matriz, a partir de 1265 y 1266; esta última vio en 1303 aumentada además su merced con la redención del almojarifazgo. Según unas ordenanzas otorgadas por los duques de Mediana Sidonia a finales del siglo XV, los vecinos de Palos de la Frontera también eran francos de pagar por lo que allí llevasen para su aprovisionamiento, así como por los productos de su labranza y crianza. Por otras de comienzos del siglo XVI, sabemos que la descarga de mercancías en el Río Tinto era quita, pero se deduce que solo las cosas adquiridas por los lugareños para llevarlas a sus casas. Si las revendían, abonarían almojarifazgo, que era del $2,5 \%$ si lo comprado era reexportado, aunque nada debía darse si se sacaba por el río. Las materias primas de fuera adquiridas por cordoneros, esparteros

13 HERNÁNDEZ, SANCHO y COLLANTES DE TERÁN, 1941: 1-8, 19-21 y 28-29. En 1389 el alcalde de los pleitos de la aduana de Carmona fallaba en favor de los vecinos eximiéndolos de tributar por la caza y pesca que introdujesen en ella, frente a la pretensión de los almojarifes que querían cobrar a los cazadores 10.000mrs., para lo que se basó en una confirmación de los privilegios locales de 1379, dada por Juan I, GONZÁLEZ JIMÉNEZ, 1976, vol. 1: 41.

14 GONZÁLEZ ARCE, 2014a: 222. AMJF, cajón 3, 22, 30, 42 y 78. 
o herreros pagaban el 5\% de arancel, frente a la franqueza disfrutada por los artículos que elaboraban. Por su parte, los zapateros y toneleros no abonaban nada por ambos conceptos ${ }^{15}$.

Del mismo modo, otras localidades fronterizas con Granada también alcanzaron el mayor grado de privilegio, en atención a su delicada situación repobladora y al peligro permanente en el que se mantuvieron a lo largo de los siglos. Los vecinos y moradores de Medina Sidonia consiguieron de Alfonso X, en 1282, franqueza de portazgo de todo lo que introdujesen y exportasen del lugar, merced ampliada por su hijo, Sancho IV, en 1288 con la exención de diezmo (almojarifazgo). Rey que fue más generoso con la vecina Tarifa, a la que exoneró en 1295 no solo de portazgo y diezmo, sino también de veintena, cuarentena y alcabalas, esto es, las alcabalas viejas; además, los mercaderes no debían dar nada por las viandas y armas llevadas al puerto de la villa, ni los bajeles ancoraje. Por otra parte, la carta puebla concedida en 1310 por Fernando IV a Gibraltar incluye la supresión del diezmo, portazgo, alcabala, montazgo, servicio, rolda, asadura, castillería y otros derechos, así como de los impuestos de las vituallas acarreadas para su abastecimiento. Ese mismo año el rey amplió la gracia otorgada por su padre a Medina Sidonia (1288) con la eliminación del pago de alcabala. Algo similar a lo ocurrido en la cercana Alcalá de los Gazules, a cuyos habitantes Alfonso XI también redimió, en 1342, de portazgo, almojarifazgo, roda, castillería, pasaje, peaje y barcaje de aquello que allí llevasen para su abastecimiento. En 1344, la feria de Tarifa quedó libre de portazgo y almojarifazgo. Y, en 1345, Medina Sidonia de la alcabala general. El último de estos tres privilegios fue confirmado por Pedro I (1350), y el primero lo extendió Enrique III a los habitantes de Arcos de la Frontera, a partir de 1399, y lo aumentó con exención asimismo de alcabalas reales, para que gozasen de iguales ventajas que los de Alcalá, Medina y Tarifa, que estaban libres de diezmo, portazgo, veintena, cuarentena, alcabalas y otros derechos, de entrada o de salida, por mar o tierra; según consta en un pleito que se desató hacia 1402 ante el alcalde de la aduana de Jerez de la Frontera, entre la villa de Arcos y los almojarifes xericenses ${ }^{16}$.

En El Puerto de Santa María Alfonso X pretendió ubicar una marina de guerra permanente, por lo que le otorgó generosos privilegios. En primer lugar, el de concesión del fuero de Sevilla, en 1281, que incluía para los vecinos exención en toda Castilla de portazgo, diezmo y otros derechos de paso; mientras que los no vecinos quedaban franqueados de pagarlos de lo que comprasen o vendiesen en la localidad. Tampoco darían nada los residentes propietarios de galeras por las mercancías que importasen y exportasen por dicho embarcadero, siempre que sus naves arribasen a éste al menos una vez

15 GONZÁLEZ ARCE, 41 (Sevilla, 2014b): 245-249.

16 GONZÁLEZ ARCE, 41 (Sevilla, 2014b): 251-252. 
al año. Los habitantes que comprasen o vendiesen géneros en otras poblaciones solamente debían abonar la mitad de los derechos correspondientes. Los comerciantes cristianos que acudiesen al lugar estaban asimismo franqueados de portazgo, mientras que a los musulmanes se les rebajó un tercio. De otro lado, los beneficios obtenidos por los moradores en el corso y la pesca igualmente fueron librados de toda tributación, siempre que lo capturado fuese vendido en la villa. En 1283 se dispuso que los barcos que remontasen el Guadalete camino de Jerez debían descargar un tercio de sus mercaderías en El Puerto. Ese año los pobladores recibieron la misma y extraordinaria merced que Murcia, para no pagar cosa alguna de lo que comprasen o vendiesen en todo el reino; luego ratificada por Fernando IV, en 1309. Cádiz y su feria lograron ventajas semejantes por parte de Alfonso X, según privilegios confirmados por sus sucesores. Tales como exención de portazgo y maltolta multa por la exportación de cosas vedadas-, en toda Castilla, en 1263, de diezmo aduanero y reducción de los derechos a abonar en la localidad por los mercaderes forasteros, $1 / 3$ menos que en Sevilla ${ }^{17}$.

\section{LAS RESTRICCIONES DEL SIGLO XIV}

Las excepcionales ventajas concedidas por la Corona a las poblaciones andaluzas ocupadas en el siglo XIII, hubieron de ser recortadas al llegar el siguiente, una vez conseguidos en parte los objetivos iniciales de repoblación y reactivación de la economía local tras la guerra de conquista. En la nueva centuria, el interés de los reyes castellanos se centró más en aumentar la presión fiscal a medida que se alejaba o disminuía la amenaza musulmana.

En las ordenanzas de Sevilla dadas por Alfonso X en fecha desconocida, quedó fijado que los artículos de los mercaderes residentes importados desde fuera del reino estaban exentos de dar portazgo al almojarifazgo, siempre que los declarasen al introducirlos en la ciudad en su aduana o en la alhóndiga del rey, donde debían jurar ser sus propietarios; tras lo que podían llevarlos donde quisiesen libremente. Del mismo modo, los vecinos estaban eximidos por los productos de su cosecha ${ }^{18}$. Sin embargo, estos amplios privilegios fueron reducidos con posterioridad, de manera que en las ordenanzas del siglo XV, si

17 GONZÁLEZ JIMÉNEZ, 1991: 293-294, 516-519, 540-541, 544 y 570-572. ROMERO, 42 (El Puerto, 2009): 36. GONZÁLEZ ARCE, 41 (Sevilla, 2014b): 249-250.

18 GONZÁLEZ ARCE, 2003: 231. Algo similar debió de ocurrir en Córdoba, donde, según las respuestas dadas a Lorca sobre cómo cobraban los almojarifes los derechos del rey, sus vecinos estaban exentos del pago de portazgo por los artículos comprados o vendidos en la ciudad, mientras que los del término lo estaban por los productos de su labranza y crianza, GONZÁLEZ ARCE, 17 (Granada, 1992): 407. 
bien se hace referencia expresa a las antedichas del siglo XIII, solo se contempla que los vecinos de intramuros con casa poblada tuviesen franqueza en sus bienes, por sacarlos o meterlos en la localidad. Y, como entonces, tenían que llevar el género introducido a la aduana, donde sería dado por quito por los almojarifes, mientras que debían obtener albalaes para poder sacar los productos de su propiedad. Pero, si salían a adquirir artículos más allá de donde vertían las aguas, un radio que luego fue fijado en 5 leguas, debían abonar los derechos correspondientes ${ }^{19}$.

Veamos cómo se produjeron estos recortes. Tras la ratificación vista más arriba de Alfonso XI de las generosas mercedes de exención de su padre Fernando IV, este rey, al año siguiente, 1327, acusó a los sevillanos de cometer abusos: como hacer pasar bienes de forasteros por suyos, y así no pagar por ellos, o dar falsos albalaes de vecindad a los extranjeros; de forma que tras examinar las libertades concedidas por sus antecesores, y atender «en qué tienpos e en qué manera fueron dadas», y puesto que habían sido aplicadas con extralimitación, decidió modificarlas. Por lo que dispuso que los moradores de intramuros quedaran exonerados de pagar por sus bienes, de lo que introdujesen o extrajesen de la ciudad por tierra, siempre que los manifestasen en la aduana. Pero si los vecinos salían del radio de 5 leguas en torno a ella —aguas vertientes-, a comprar mercancías y llevarlas allí, y pretendían hacerlas pasar por suyas y por francas, las perderían, así como sus privilegios de exención. Por otra parte, todos, vecinos y foráneos, que llevasen mercancías a Sevilla por mar pagarían de entrada veintena (5\%) y de salida cuarentena (2,5\%), como vimos para Murcia, con los retornos exentos; si bien se mantenía el arancel del $10 \%$ para lo exportado a Granada, excepto el aceite del que previamente se hubiese dado el diezmo del Aljarafe, que era franco. Dos años más tarde, en 1329, el monarca parece que reconsideró esta restricción de mercedes y de nuevo puso en vigor las franquezas concedidas por su padre. Tal y como prometió el hijo de Alfonso, Pedro I, en 1351, que, sin embargo, ese mismo año lo que revigorizó fueron en parte las reducciones de las ventajas fiscales de 132720 .

En 1577 el concejo hispalense inició un pleito, que ganó, contra los arrendatarios del almojarifazgo de Indias, que no respetaban la libertad de los vecinos para exportar productos de su labranza y crianza. En la sentencia ejecutoria se recogen los privilegios en los que se asentaba esa gracia: uno de confirmación de Pedro I (1351), que recoge otro anterior suyo (del mismo año) por el que ratificaba uno de su padre, Alfonso XI (1329), que a su vez validaba los dos de Fernando IV (1297 y 1304), mediante los que, a petición de la localidad, la eximía de portazgo, diezmo, veintena y demás derechos.

19 ORDENANZAS DE SEVILLA, 1632, fols. 55r, 64r.

20 GONZÁLEZ ARCE, 2003: 252-253. COLLANTES DE TERÁN, 41 (Sevilla, 2013): 300-303. 
Los de Fernando y Alfonso liberaban a los sevillanos de todo tipo de tributos de todo lo que compraren y vendieren, metieren y sacaren, en toda Castilla, tanto por mar como por tierra. Mientras que el primero de Pedro mantuvo el statu quo vigente, hasta que celebrase Cortes en la ciudad y determinase al respecto. Cuando se celebraron éstas, dispuso, según el segundo de los privilegios arriba referidos como emitido por este rey, que los sevillanos fuesen redimidos de diezmo y veintena solo por los artículos de su labranza y crianza introducidos o extraídos por mar o tierra en la población; si bien quedaban exonerados de abonar portazgo en toda la Corona por toda clase de mercancías. Aunque, por el contrario, sí debían pagar el derecho de almojarifazgo en las aduanas de los lugares fronterizos. Gozarían de esta merced los vecinos de Sevilla, los forasteros avecindados más de un año y los extranjeros que lo estuviesen más de diez ${ }^{21}$.

En 1393 Murcia envió un mensajero a Toledo, Córdoba y Sevilla, ciudades con las que compartía usos forales y exención de almojarifazgo, para que le informasen sobre los términos de la misma. Quería saber si se aplicaba a la grana y madera de los términos municipales, así como a los paños fabricados con lana local, o si los hidalgos gozaban de libertad para la importación de esa materia prima y de tintes con destino a la industria textil. La capital hispalense respondió que, desde tiempos de la conquista, sus vecinos estaban libres de almojarifazgo y otros derechos, como portazgo y diezmo, de cuantas cosas comprasen o vendiesen, llevasen o trajesen, tanto por mar como por tierra. Sin embargo, tras Sancho IV, los reyes posteriores quebrantaron esas libertades, de forma que desde Enrique II solamente afectaban a las cosechas de los habitantes — cereal, vino, ganados, aceite, cueros, miel, cera y lana-, y a los paños, tanto si los vendían en tierra como si los exportaban por mar'22.

La villa de Utrera habría recibido de Enrique II, en 1369, al comienzo de su reinado, y por tanto como una de las amplias mercedes concedidas por dicho monarca a sus partidarios tras su ilegítimo ascenso al trono, franqueza de almojarifazgo, diezmo, veintena y portazgo, es decir, toda suerte de tributos comerciales, excepto alcabala. El concejo de Sevilla, a cuya jurisdicción pertenecía la localidad, había respetado el citado privilegio hasta 1492, cuando ordenó a sus alcaldes fallar a favor de los almojarifes en los pleitos que ante ellos llevasen. Lo que implica que la exención de almojarifazgo no debía concernir únicamente a los derechos de tránsito, sino también al almojarifazgo concejil, o rentas pertenecientes a los propios de la ciudad de Sevilla. Los Reyes Católicos mandaron a los alcaldes que no cumpliesen la disposición del

21 AGS, Patronato Real (PT), Libro de Copia (LC), 4, fols. 33-45. En 1717 todavía se debatía cómo se debía entender esta exención de almojarifazgo, AMS, Privilegios, carpeta 3 y 73.

22 GONZÁLEZ ARCE, 99 (Murcia, 1999): 95-101; 2012: 672-683. COLLANTES DE TERÁN, 41 (Sevilla, 2013): 294-296. 
consistorio. Más claro queda este extremo en Coria, pueblo perteneciente también a la jurisdicción sevillana, cuyo concejo se dirigió en 1472 al de la capital para exponerle que, como los habitantes de la misma y los de otras poblaciones de ésta dependientes, consideradas como guardas y collación de la ciudad, sus vecinos y moradores estaban exonerados, según privilegios de los monarcas precedentes, del pago de almojarifazgo por las cosas de su labranza y crianza, así como por los suministros que allí llevasen para su abastecimiento. De manera que el almojarifazgo concejil que en ella se demandaba, arrendado por el ayuntamiento capitalino, debía recaer tan solo sobre los mercaderes y regatones que en ese lugar, y otros como ése, introducían algunos artículos o allí los compraban y vendían, pero no sobre sus pobladores. Sin embargo, el arrendatario de ese año en la villa, Diego de Prueda, sí que lo exigía a los susodichos, al tiempo que se dejaba cohechar para dejar de acosar a quienes no lo abonaban y no demandarlos en pleito, mientras que otros lo pagaban por ignorancia ${ }^{23}$.

\section{SIGLO XV, CONSOLIDACIÓN DE PRIVILEGIOS Y NUEVAS EXENCIONES}

Tras las restricciones del siglo anterior, las localidades privilegiadas con exenciones en los derechos de tránsito pugnaron por mantener sus mercedes, aunque fuese en su extensión mínima. Que, como hemos visto, en términos generales, comprendían a los vecinos, a veces también a los residentes habituales con patrimonio en la población, que eran francos de abonarlos, total o parcialmente, por los productos de su cosecha, crianza o elaboración que exportasen o por los alimentos y materias primas importados. Además, la reanudación de la guerra de conquista contra el reino de Granada trajo como consecuencia la incorporación de nuevos territorios, que, como ocurrió en el siglo XIII, eran difíciles de repoblar por haberse convertido en la nueva e insegura frontera con el Islam. De manera que, como ocurrió entonces, los recién fundados concejos recibieron similares privilegios de franqueza en materia de tráfico de mercancías. Algunos permanentes, otros temporales. Unos más generosos que otros,

23 El documento dice que la gracia la había concedido el rey Enrique en el «año» 1407, sin embargo debió de ser Enrique II en la «era» de 1407 (1369), pues Enrique III falleció en 1406, FERNÁNDEZ, OSTOS y PARDO, 1997, vol. 6: 38-41. Ese privilegio de exención pudo ser el que esgrimieron en 1455 los carniceros de la villa, cuando reclamaron ante el concejo de Sevilla porque los almojarifes de la ciudad les embargaban los cueros del ganado que sacrificaban y llevaban a vender a la capital, cuando, según dicha merced, estaban libres de abonar almojarifazgo, AMS, Acta Capitular (AC) 1455, agosto-octubre, fol. 69. En cuanto a Coria, AMS, AC 1472, ago-dic, fol. 40. 
en función de las coyunturas bélicas, económicas y políticas, de las estrategias repobladoras y comerciales, o de la relevancia de cada emplazamiento ${ }^{24}$.

\section{Viejos privilegios y nuevos conflictos}

El litigio del año 1402, citado más arriba, entre el alcalde de la aduana de Jerez y la villa de Arcos, estuvo motivado en la reivindicación de la mencionada localidad, apoyada en su privilegio real sobre el derecho de sus vecinos a pasar libremente con mercancías y sus mantenimientos, y sin informar a los almojarifes, por el camino que venía desde Medina Sidonia y por el que iba a Sevilla y a Alcalá de los Gazules, que atravesaban el término jerezano, el cual no les era respetado por éstos. Este proceso fue ganado por el concejo arcobricense. Del mismo modo, en el primero de los cuadernos del almojarifazgo de 1497 dado por la duquesa de Arcos a dicha ciudad, sede principal de sus señoríos, se dice que si los habitantes de ésta llevaban sus mercancías a vender a Jerez u otras partes de la comarca, tanto esos vendedores como los compradores locales no debían abonar nada al almojarife arcense; pero si la venta tenía lugar en el término de Arcos, debía ser comunicada al mismo para hacerle entrega de su derecho del 5\%, una vez cobrado por el vendedor al comprador ${ }^{25}$.

Sobre el quebramiento de las exenciones de Jerez de la Frontera por las localidades vecinas me he ocupado en un reciente trabajo. Caso de lo ocurrido en Lebrija, villa de jurisdicción sevillana fronteriza con Jerez donde, si bien desde 1391 existía un acuerdo suscrito entre Sevilla y Jerez para no exigirse mutuamente derechos entre ellas, no siempre fue respetado. De modo que en la década de 1480 volvieron los roces y debieron ser emitidas varias cartas para que se respetase lo pactado en 1391, y que sus respectivos vecinos fuesen libres de almojarifazgos municipales en los términos de la otra población. Por esas fechas del siglo XV, en El Puerto de Santa María y en Cádiz a veces también exigían a los jerezanos tributos contrarios a su franqueza para adquirir y vender libremente mercancías de su cosecha o para su abastecimiento, como los llevados por el transbordo de mercancías entre barcos en el río Guadalete o las alcabalas y otros por las compraventas. En Trebujena, hacia 1490, les impusieron nuevas tasas en el puerto fluvial de Alventos. Mientras que en

24 Una política similar de franquicias fiscales fue seguida por Florencia con los territorios que conquistó entre los siglos XIV y XV, EPSTEIN, 2009: 195. Sobre este fenómeno en otros lugares de Europa, como Cataluña, FONT, 1983; Gascuña, GOURON, 1935; Normandía, BAUDUIN, 2001; Prusia, FERNÁNDEZ HERNÁNDEZ, 44 (Murcia, 2007) y la Europa del noreste, CHRISTIANSEN, 1997.

25 GONZÁLEZ ARCE, 41 (Sevilla, 2014b): 251. 
la propia ciudad también hubo problemas con los almojarifes locales y, sobre todo, con los sevillanos. Estos últimos, hacia 1433 no querían dar licencias para la entrada de paños y otros bienes exentos desembarcados en Cádiz, o llevados por tierra, pues algunos eran reexportados hacia Sevilla y otros lugares de forma fraudulenta. En ocasiones a los jerezanos tampoco les era respetada la franqueza de tránsito de sus ganados, como en los años 60, durante la guerra civil, o se les exigían gravámenes sobre la carne, aunque fuese de origen local. El vino también se vio afectado, y en 1496 el factor de los almojarifes lo demandó de un vecino por la salida del suyo de su cosecha, a lo que el corregidor contestó que podía llevárselo francamente, como siempre, con el correspondiente albalá del fiel de la aduana. Poco después era admitida por el concejo la carta de recudimiento del almojarifazgo sevillano, en el que se incluía el de Jerez, pues el arrendatario, Fernán Núñez Coronel, había accedido a exigir solo el $2 \%$, y no el 2,5, del valor del vino comprado en la ciudad y sacado de ella ${ }^{26}$.

En general, vemos que como población fronteriza, que mantuvo su situación de peligro hasta bien entrado el siglo XV, Jerez supo mantener en mayor medida su situación de privilegio fiscal frente a otras como la propia Sevilla que, por su mayor seguridad y pujanza económica, fue perdiendo con el tiempo parte de sus ventajas arancelarias.

Cuando Puerto Real fue segregado de Jerez, en 1483, para convertirlo en un fondeadero marino de realengo, frente a los de su entorno pertenecientes a grandes señores territoriales, los Reyes Católicos eximieron a los mercaderes por todas las mercancías descargadas en su embarcadero del pago de alcabala y otras exacciones, y les dieron seguridad durante 20 días para no ser embargados ni presos por delitos cometidos en otras partes, o de 60 para las deudas civiles y contratos. Además, el género que entrase en la villa y luego no se vendiese podía ser reexportado, asimismo sin pagar cosa alguna, siempre que se llevase fuera de Castilla; si iba a ser colocado en otras tierras castellanas sí satisfaría el $1 \%$ de su valor; misma tasa que se cobraría a las mercaderías de otras partes llevadas a dicho amarradero para ser exportadas por mar, excepto al cereal, que era franco. No obstante, durante los primeros cinco años tras la fundación, todos los que comprasen algunos artículos en la población llevados de fuera, incluidos subsistencias, deberían abonar el 3\%. Como dicha exención de derechos resultaba ambigua con respecto al almojarifazgo, como ocurrió con las del siglo XIII, Carlos I hubo de aclarar en 1525 que a partir de 1530, cuando finalizase el arrendamiento en vigor, dicho impuesto no se exigiría a los productos de la labranza y crianza de sus vecinos, que también estaban libres de alcabala, pero sí, por consiguiente, a los que no lo fuesen, esto es, a los provenientes de fuera. En 1554 se desató un pleito entre el concejo

26 GONZÁLEZ ARCE, 2014a: 222-224, 229 y 235-247; 41 (Sevilla, 2014b): 251. AMJF, cajón 1, 24; AC 1496, fols. 90v, 113r-v. 
de Sevilla, que tenía encabezada la renta, y el de Puerto Real, debido a que el primero acusaba a los fieles del almojarifazgo nombrados por el segundo de conceder licencias a muchas personas para sacar vino del lugar sin entregar el impuesto, mientras que éste se amparaba para ello en los privilegios y disposiciones reales antedichos. Un juez sentenció en primera instancia que no se pudiesen otorgar tales permisos a los forasteros sin que antes cumpliesen con el gravamen. Si bien éste sería de solo el 1\% más arriba visto, según la sentencia dada tras la apelación portorrealeña; lo que no gustó a los demandantes, que pidieron que satisficiesen el 2,5\%, como por las restantes exportaciones hechas desde el reino de Sevilla, según el arancel del almojarifazgo. Lo que no fue tenido en cuenta en la sentencia definitiva, que ratificó la anterior ${ }^{27}$.

En 1451 los procuradores de Sevilla y Córdoba denunciaron ante Juan II que, a pesar de que sus respectivas ciudades tenían privilegios, por él confirmados, que las eximían del pago de almojarifazgo, portazgo y otros derechos por 2.000 pinos anuales importados para su aprovisionamiento, algunas localidades ribereñas del Guadalquivir les demandaban nuevos tributos a su paso. Éstos eran, además, contrarios a las condiciones contenidas en el cuaderno de arrendamiento por seis años del almojarifazgo dado en 1446 a Córdoba, que, explícitamente recogía dicha exención ${ }^{28}$.

En 1492 el concejo hispalense solicitó del arrendatario del almojarifazgo, el tesorero Pedro González de Madrid, testaferro de Fernán Núñez Coronel, que era el verdadero almojarife, que respetase los privilegios, usos y costumbres de la ciudad en el caso de la franqueza de los vecinos para no pagar cosa alguna de los productos de su labranza y crianza que sacasen o metiesen en ella, algo que también atañía a los caballeros locales, sin que el género debiese pasar por la casa de la aduana, bajo juramento de los propietarios de que lo que transportaban era de su cosecha y no había sido vendido ni se había convenido hacerlo, tras lo cual obtendrían la pertinente cédula para su tránsito sin

27 AGS, PR, LC, 4, fols., 12r-33r; 5 fols., 189v-210v.

28 AMCo, caja 1 y 36. En 1450 eran los almojarifes sevillanos los que protestaron ante el concejo hispalense porque había concedido licencia a un vecino para llevar a una de las puertas de la ciudad 400 pinos francos, pues todas las mercancías, también las francas, debían ser pasadas por la aduana antes de ser descargadas o contar para no hacerlo con el preceptivo albalá de los almojarifes; además, tales troncos no estaban libres de pagar los derechos de almojarifazgo. De esta manera, los arrendatarios conminaron al consistorio a revocar su carta o se querellarían contra él por cuantía de 400.000 mrs., que es en lo que estimaron el valor de dicha madera, AMS, AC 1453, ene-mar, fol. 27. Uno de los artículos que estaban exentos de pagar almojarifazgo y alcabala al ser introducidos en Sevilla eran los metales preciosos, oro y plata, así como el vellón y cobre. En 1431 Juan II ordenó acuñar nuevas monedas y hubo de actuar ante la queja de los monederos locales porque los almojarifes no querían respetar dicha franqueza, AMS, AC 1431, fols. 53r-54v. En 1466, a petición de la localidad y en atención a los servicios prestados, Enrique IV concedió a Jaén y sus habitantes exención de portazgo y almojarifazgo en toda Castilla para los productos de su propiedad, RODRÍGUEZ, 1985: 37-38. 
pagar nada. En tiempos de Carlos I y Juana I, la propia Sevilla protestó por los abusos cometidos por los almojarifes y sus guardas, al realizar extorsiones y cohechos con los comerciantes, lo que llevó al ayuntamiento a plantearse el encabezamiento del impuesto para poder eximir de su pago a las mercancías exportadas por tierra, que era donde mayormente se cometían las irregularidades. También solicitó de los monarcas que, de no consentir dicha solicitud, al menos otorgasen la citada exención; con el argumento de que lo que se dejase de recaudar se compensaría con la importación de más productos por mar, ya que el incremento de la riqueza de los vecinos, al desaparecer el gravamen sobre las exportaciones terrestres, aumentaría su demanda de artículos de fuera. La respuesta real fue que no se podía dar el encabezamiento, que finalmente sí tuvo lugar, si no se hacía de forma desagregada, esto es, cada puerto de los que estaban en el arrendamiento por separado, y que aun así esto sería perjudicial porque entrarían en competencia entre ellos. De manera que, en reconocimiento por los servicios prestados a lo largo de la historia por la población, a partir de 1526, cuando finalizaba el arrendamiento de seis años vigente en ese momento, todos, los vecinos y los forasteros, quedarían franqueados del almojarifazgo de los bienes que sacasen de ella por tierra. Mientras no expirase el susodicho arrendamiento, se les eximía de pagar por los productos exportados por tierra contemplados en el acuerdo que el arrendatario Fernando de Cuenca había suscrito con el consistorio, aunque se hiciesen nuevas pujas sobre la renta. De forma que los guardas ya no tendrían potestad para inspeccionar el tráfico comercial terrestre ni oportunidad de expoliar a los mercaderes ${ }^{29}$.

Carmona, a la que vimos privilegiada con exenciones de tributos sobre el tráfico comercial en el siglo XIII, obtuvo en 1466, durante la sublevación del príncipe Alfonso, hermanastro de Enrique IV, del maestre de Calatrava, titulado virrey de Andalucía, una feria franca libre de alcabalas y almojarifazgo, salvo el $2 \%$ en sustitución de ambas exacciones. Meses más tarde le fue confirmada por el impostor. Mientras que tres años más adelante, en 1469 era el

29 AMS, AC 1492, fol. 45v. AGS, PR, 59 y 150. En un año indeterminado del reinado de los Reyes Católicos, los candeleros sevillanos protestaron ante el consistorio porque los almojarifes les hacían llevar los productos de sus colmenas a la casa de la aduana y no les dejaban ir directamente con ellos, con el preceptivo albalá, a sus domicilios, en contra de los privilegios de franqueza de la ciudad y del arancel de 1491 del almojarifazgo, recientemente aprobado, que establecían que los vecinos estaban exentos del pago de almojarifazgo por los artículos de su labranza, salvo en el caso de que los vendiesen, que debían satisfacer la alcabala, AMS, AC siglo XV, sin fechas, fol. 78. En 1453 Juan II hizo saber a los contadores mayores que Pedro García de Huete, deán de Toledo, capellán mayor, oidor de la audiencia y fedatario del Consejo real, prior del priorazgo de Aracena, había hecho relación al rey de que los priores anteriores siempre acostumbraron meter en Sevilla lino, vino, frutas y otras cosas de los diezmos y rentas del priorazgo, sin pagar por ello rodas, barcajes, portazgo, peajes, almojarifazgo, aduana, ni ramo ni otro derecho alguno, de lo cual tenían privilegios y cartas firmadas por el monarca, AGS, Mercedes y Privilegios, 3 y 17. 
propio rey Enrique IV el que le otorgaba una merced similar, pero en este caso especificaba que ese $2 \%$ recaudado de todo lo que se vendiese o comprase durante la feria sería repartido prorrateado entre los arrendatarios de ambas rentas. Más adelante, en 1472 la villa firmó una hermandad con su vecina Sevilla, similar al acuerdo arriba visto entre Jerez, Lebrija y la capital hispalense. En este otro caso, los vecinos de ambos lugares podían aprovecharse de los términos concejiles del otro municipio y también circular libremente por él con sus ganados y mercancías sin abonar gravamen alguno.

Convenio que no siempre fue observado. Así, en 1478 la villa hubo de reclamar ante el consistorio sevillano porque en algunos lugares y concejos de su tierra y jurisdicción les exigían rodas, portazgos y castillería. Además, le recordó que la misma contaba, al estar poblada según el propio fuero de Sevilla, con franqueza de almojarifazgo en favor de sus vecinos y moradores, de las cosas que llevasen y trajesen a la localidad; lo que no les era respetado en Coria, donde les demandaban dicho almojarifazgo y barcaje, así como en Alcalá de Guadaíra y en el pasaje en Utrera. La respuesta del ayuntamiento hispalense fue que esas nuevas tasas correspondían a derechos de paso para pagar las imposiciones de la Santa Hermandad, autorizados por los Reyes Católicos; si bien accedió a que a los carmonenses no se les cobrase el almojarifazgo concejil en Sevilla, como siempre se había hecho. Posteriormente, en 1484 los almojarifes municipales sevillanos no respetaron el concordato y volvieron a llevar derechos a los de Carmona. Al igual que el año siguiente, 1485, cuando un calderero carmonense denunció ante un alcalde de Villanueva del Camino, lugar de Sevilla, al arrendatario del almojarifazgo local, Juan Batifora, por haberle reclamado su pago por los artículos allí vendidos en contra de la antedicha hermandad, a pesar de portar una fe en la que constaba que era vecino de Carmona y, por tanto, exento. Por su parte, el arrendatario mostró el cuaderno de las condiciones de cobro del mismo, que tenía más de 40 años, que disponía que los que no fuesen vecinos del cuerpo de Sevilla debían abonarlo por todo lo que metiesen y sacasen, comprasen o vendiesen. El alcalde falló en favor del almojarife y el calderero solicitó una fe notarial del veredicto que presentó al concejo de Carmona. En 1494 la protesta de esta villa contra la de Villanueva era por el derecho de la varga, renta incluida en el almojarifazgo del lugar, que contra su franqueza se había cobrado a un carmonense. Ese mismo año, un jurado de Carmona expidió otra fe de vecindad para que a un curtidor no le llevasen tributo alguno, incluido almojarifazgo, los arrendatarios de las barcas, rodas, portazgos, montes y términos de Sevilla, en virtud de la citada hermandad. En 1500 el ayuntamiento de Carmona tomó declaración a ciertos vecinos de lo que les habían cobrado indebidamente en Sevilla, en su alhóndiga, y en otras partes de su tierra, en concepto de barcaje, roda, portazgo y almojarifazgo; en total fueron más de 40 los que prestaron testimonio. Esta actuación se enmarcó dentro de un proceso de guerra abierta entre ambas localidades que no 
respetaban sus franquezas y, contra la hermandad suscrita entre ellas, se tomaban prendas mutuamente. Lo que hizo intervenir a los Reyes Católicos, que les ordenaron observar dicho acuerdo y devolver las requisas ${ }^{30}$.

Como vimos más arriba, los gaditanos estaban exentos desde el siglo XIII del pago de todo tipo de gravámenes aduaneros, mientras que los forasteros abonaban en Cádiz al almojarifazgo 1/3 menos que en Sevilla. Práctica que había caído en desuso y, por tanto, no daban nada, hasta que fue puesta en vigor de nuevo por los Reyes Católicos. Quienes, a petición de la ciudad, y ante el temor de su despoblamiento, dispusieron en 1502 que solamente satisficiesen una tasa reducida del $1 \%$ de todo lo que se importase o exportase fuera de Castilla, aproximadamente $1 / 3$ del $2,5 \%$ con que estaban gravadas las exportaciones en el arancel del almojarifazgo de 1491, tal y como hemos visto para Puerto Real, y como se había acordado con los almojarifes de Sevi$\mathrm{lla}^{31}$. En un pleito sostenido hacia 1512 por el arrendatario del almojarifazgo mayor de Sevilla, Pedro de Santa Cruz, contra Cádiz, ésta presentó un escrito de los Reyes Católicos, fechado también en 1502, según el cual la ciudad había sido requerida por los contadores mayores, a petición de los arrendatarios, para que allí se pagase el impuesto, a lo que contestó con la remisión a los primeros de sus privilegios. De los que se desprendía que se debían abonar solo las 2/3 partes del cargo y descargo de la mar de lo que se daba en Sevilla, como acabo de decir. La respuesta de los soberanos a la petición del concejo gaditano de que se mantuviese este estado de cosas fue que la renta ya se hallaba arrendada y que se debían cumplir sus condiciones. Entre ellas, un asiento firmado por los arrendatarios para que las mercancías descargadas y puestas bajo la custodia de los agentes de los almojarifes, sin ser vendidas, no pagasen tasa alguna, como tampoco las que se desembarcasen para reparar los navíos averiados y luego se volviesen a embarcar. Aunque lo reexportado desde ese puerto fuera de la Corona estaría gravado con el 1\%. El resto de lo allí llevado se regiría según el citado arancel de 1491. En 1543, la ciudad de Sevilla, que tenía encabezado su almojarifazgo mayor, llegó a un acuerdo con

30 HERNÁNDEZ, SANCHO y COLLANTES DE TERÁN, 1941: 65-66. AMCa, AC 1469, fol. 401r; 1484, fols. 290r-295v; 1485, fol. 10; 1494, fol. 324r-v. AMCa, leg. 1.120. AMCa, lib. 405, tumbo, fols. 75v-76v. AMS, AC 1478, ago-sep, fol. 77r-78v; sep-nov, fols. 38v y 61v. En 1476 era Mairena (del Alcor) la que protestó ante Carmona porque a un vecino le habían cobrado derechos en la aduana carmonense, en contra de la buena vecindad entre ambas villas, por la que sus respectivos lugareños estaban exentos en el otro municipio; irregularidad que ya había ocurrido otras veces anteriormente. En 1489 era un alcalde de Utrera, ésta perteneciente como sabemos a la tierra de Sevilla, el que expuso ante el encargado de la aduana de Carmona cómo le habían llevado cierta prenda por una carga de sayal que por allí pasó, en represalia por ciertos derechos que los almojarifes de Utrera habían cobrado de vecinos carmonenses, AMCa, AC 1476, fol. 23; 1489, fol. 182; 1500, fols. 266r-268v, 306r-308r.

31 AGS, PR, LC, 5, fols. 359-421. 
Cádiz por el que se fijó para esta última un padrón especial para los productos llegados o sacados de su puerto ${ }^{32}$.

Durante el reinado de Juana I, El Puerto de Santa María inició un litigio contra los almojarifes de Sevilla para hacer valer su exención de sal, vino y pescado, tanto de carga como de descarga, así como de todos los bastimentos de sus navíos surtos en su surgidero, tanto mercantes como pesqueros, de la sal para la salazón del pescado y de los paños cargados y descargados en su embarcadero ${ }^{33}$.

\section{Nuevos territorios y nuevos privilegios}

En 1477, el I marqués de Cádiz y III conde de Arcos, Juan Ponce de León, fundó el lugar de Chipiona, donde con probabilidad existió previamente una aldea perteneciente al término de Rota. Con el fin de atraer a nuevos habitantes, el señor concedió una carta puebla. En ella se les eximía durante los primeros quince años de todo tipo de tributos reales y concejiles — pedidos, monedas, servicios...-, e incluso los liberó del pago de almojarifazgo y alcabalas, tanto en la propia Chipiona como en Rota; si bien debían comunicar sus tratos con forasteros al recaudador/arrendatario señorial de estos derechos. Tales forasteros sí correrían con estas tributaciones, aunque obtuvieron sustanciales rebajas en comparación a lo que se demandaba en Sevilla. Durante los cinco años iniciales de la fundación solo satisfarían de almojarifazgo el 2,5\%, y el 5 en concepto de alcabala; mientras que en adelante ambos quedaron en el 5-10\%, respectivamente. Trascurridos los quince años de gracia, los nuevos pobladores pagarían los mismos derechos que los roteños, incluidos almojarifazgo y alcabala ${ }^{34}$.

Gibraltar, que fue conquistada definitivamente por Castilla en 1462, obtuvo como otras plazas de reciente ocupación exenciones para la importación de suministros, al menos durante los primeros tiempos. Así, dos años más tarde, 1464, el pagador real de la ciudad expuso a Enrique IV su temor de que si no se les proporcionaban bestias y carros para llevar mercancías, y si los almojarifes de Sevilla no respetaban dicha franqueza, la misma no podría ser avituallada. De modo que el monarca tasó el precio de los medios de transporte y mandó a los recaudadores que no exigiesen nada de dichos abastos para los vecinos del lugar. En una fecha indeterminada, los almojarifes se quejaron ante la reina Juana por los fraudes y extralimitaciones cometidos por los gi-

32 AGS, Cámara de Castilla (CC), Diversos, 3, 84 y 105. AGS, PR, LC, 5, fols. 386v389r y 401v-407v.

33 AGS, CC, Diversos, 4 y 105. ROMERO, 42 (El Puerto, 2009): 52-53.

34 GONZÁLEZ ARCE, 41 (Sevilla, 2014b): 269. 
braltareños, so pretexto de su privilegio de franqueza dado por los Reyes Católicos en 1502, que se ceñía a los productos de su crianza y labranza, así como a la importación de ciertas mercancías por los vecinos, 60 toneles de aceite, subsistencias y artículos de alfarería, sobre todo.

El arrendatario del almojarifazgo mayor de Sevilla del año 1512, el susodicho Pedro de Santa Cruz, expuso ante la monarca que los vecinos de Palos se habían negado a abonar la exacción, con el argumento de ser francos en sus labranzas y crianzas. Como no pudieron demostrar este extremo, cargaron contra el arrendatario con la acusación de que en la aduana de la localidad no estaban expuestas las leyes de recaudación de dicho impuesto; la soberana ordenó en 1516 el pago del gravamen. Algo similar intentaron los malagueños, con su privilegio de 1501, o los almerienses con el suyo, también de ese mismo año pero mucho más generoso, asimismo en 1512, que ahora veremos ${ }^{35}$.

En la segunda mitad de los años 80 del siglo XV, a medida que la guerra de Granada se desplazaba hacia el este, los Reyes Católicos sentaron las bases para atraer gentes con las que repoblar las zonas conquistadas, que, como en el siglo XIII, consistieron en la concesión de franquezas sobre la circulación de personas y mercancías. Exenciones que, como entonces, no siempre fueron respetadas por las autoridades locales que controlaban los caminos, por lo que hubieron de ser refrendadas en diversas ocasiones; caso de lo ocurrido con Marbella, Málaga y Vélez-Málaga. Se trató de mercedes circunstanciales encaminadas a garantizar el poblamiento inicial a través de la liberación de las subsistencias, sin que todavía se hubiese decidido nada acerca de la fiscalidad que gravaría la producción o el tráfico comercial ${ }^{36}$.

\section{Analísis de los casos más relevantes}

En 1478 Isabel y Fernando confirmaban al conde de Ureña una merced dada por Enrique IV para que los vecinos de su villa de Archidona, en ese momento fronteriza con Granada, fuesen exentos de monedas, fonsaderas,

35 AMJF, AC 1464, fols. 81r-82v. AGS, CC, Diversos, 3, 6, 14 y 35; 4 y 108. AGS, PR, 36 y 19. En 1511 era fallado por la Chancillería de Granada un pleito entre el arrendatario del almojarifazgo de Málaga del año 1510, Gonzalo del Puerto, y un vecino de Gibraltar que había introducido por el embarcadero malagueño 99 jarras, 11 botas y 5 pipas de vino de su cosecha, por valor $25.000 \mathrm{mrs}$., de lo que debería haber pagado $1.200 \mathrm{mrs}$. en concepto de almojarifazgo —a razón del 5\%-; en su defensa el gibraltareño esgrimió el privilegio de exención que convertía en franco al vino local, al tiempo que presentó un certificado de avecindamiento y otro del diezmero como que el género era de su cosecha; sin embargo, el almojarife alegó que el vino no era suyo propio, por lo que consiguió que fuese condenado a pagar el impuesto, AGS, CC, Diversos, 3 y 83.

36 LÓPEZ DE COCA, 2 (Málaga, 1979): 207-208. 
servicio, barcaje, roda, portazgo, peaje, alcabala, almojarifazgo y otros pechos, de todo lo que comprasen, vendiesen o llevasen por todo el reino ${ }^{37}$. En 1487 los soberanos hicieron libres a los pobladores de Málaga del pago de almojarifazgo, portazgo, roda, castillería y otros derechos por los bienes muebles o semovientes que con ellos llevasen. Como siempre, el grado de generosidad en las exenciones estuvo marcado por lo atractivo que resultaba el territorio que con ellas se quería repoblar, de manera que fueron mayores para las zonas inseguras y las pequeñas localidades. Como Montefrío, que meses antes que Málaga obtuvo no solamente franqueza de tributos de tránsito, sino también de alcabala, y no únicamente para los bienes de los nuevos pobladores, sino también para los abastecimientos que para ellos allí fuesen transportados. Algo que en 1490 fue ampliado a todas las localidades hasta entonces conquistadas en el reino de Granada, cuyos suministros fueron franqueados de gravámenes de paso, incluido almojarifazgo. En 1498 el concejo de Lorca solicitó de los monarcas que fuese cumplida esta pragmática y de este modo no se les exigiese a los lorquinos imposiciones por los ganados que llevasen por los términos de Vélez Rubio y Vélez Blanco, por las mercancías que transportasen hacia Andalucía o por la pastura en Huéscar ${ }^{38}$.

A partir de 1490, debido al poco brío repoblador, las franquicias aumentaron en generosidad, pero fueron concedidas por tiempo limitado. De manera que a las exenciones de las subsistencias se sumaron las que afectaban al tráfico comercial general. Ese año los vecinos de Baza obtuvieron redención de alcabala y derechos de paso por los bienes y mantenimientos que introdujesen en la villa. Poco después, los de Almuñécar y Almería consiguieron por diez años ventajas similares, y quedaron libres de alcabalas y exacciones de paso de todo lo que importasen o exportasen, por mar o tierra; a excepción de cosas vedadas y seda. Mientras que los forasteros podían importar toda suerte de mercancías en las mismas condiciones. Mercedes de las que no gozaron los vecinos mudéjares ni judíos, ni los mercaderes italianos. En 1491 eran Málaga y Benalmádena las que obtenían idéntico privilegio; mientras que los habitantes de Baza y Guadix fueron premiados con gracias similares — si bien nada se dice de la exención por mar-, aunque solo por tres años; no obstante, en 1494 los de Vera y Mojácar las recibieron de nuevo por diez anualidades ${ }^{39}$.

Llegamos así al caso de la ciudad de Granada, el más peculiar de todo el reino. Pues, si como en otros lugares, tras la conquista de 1492 y hasta 1495

37 AHN-SN, Osuna, caja 61 y 29-34; caja 65 y 47. En 1485 esta villa, así como Osuna, Morón, El Arahal y Olvera pertenecían a Juan Téllez Girón, quien ese año concedió un privilegio a la última para eximir a sus vecinos en las restantes del pago de portazgo, veintena, alcabala y almojarifazgo señoriales de todo cuanto comprasen y vendiesen, ROJAS, 1987: 192.

38 AGS, Registro General del Sello, 1487-04, 15; 1487-10, 4; 1490-11, 51. GARCÍA DÍAZ, 2007: 250-252 y 375-378.

39 AGS, PR, 59, 154. FERNÁNDEZ, OSTOS y PARDO, 1997, vol. 6: 204-209. 
quedaron anuladas las cargas para los repobladores que a ella acudiesen y para sus bienes, así como para el abastecimiento de mantenimientos, hasta ese momento, cuando se mantuvo la estrategia de conciliación con los mudéjares, éstos gozaron de mayores exenciones que los nuevos habitantes cristianos. Sin embargo, desde dicho año cambió la política real y se sucedieron una serie de mercedes para estos últimos, claramente privilegiados desde entonces frente a la población nativa. Así, como en ejemplos anteriores, en 1495 le fue concedida a los repobladores una franqueza por diez años sobre el tráfico de subsistencias, tanto locales como importadas, pero solo en los tratos entre cristianos y sin incluir la seda. Luego llegaron las remisiones de alcabala y diezmo y medio diezmo de lo morisco para artículos no considerados como básicos; exacciones que se debían abonar, no obstante, en el trato con los mudéjares. Beneficios que se extendieron a las alquerías de la Vega granadina, Santa Fe, Alpujarras y la costa, siempre en favor de los cristianos. Conviene recordar que, una vez conquistado el reino de Granada, como previamente ocurriera con otros como el de Toledo, éste se unió a la Corona castellana en forma de acapeto, esto es, mantuvo una personalidad jurídica y legal diferenciada; que en el caso de la fiscalidad se tradujo en que se conservasen los mismos impuestos que existieran antes de la ocupación castellana. Incluidos los gravámenes aduaneros terrestres con los reinos vecinos de Sevilla, Córdoba o Murcia, en cuyos puertos secos y pasos fronterizos se exigió el citado diezmo y medio diezmo de lo morisco a los mercaderes no granadinos, salvo algunos exentos, como los sevillanos, que vimos más arriba, equivalente al almojarifazgo que se cobraba en las fronteras de esos otros reinos, incluso a los flujos comerciales efectuados dentro de la propia Corona. Por otra parte, las mercancías llegadas o sacadas por mar desde los puertos del reino cristiano de Granada no tributaban el citado diezmo y medio diezmo sino, como en Sevilla y Murcia, también almojarifazgo, según un arancel propio.

Casi todas estas poblaciones vieron prorrogadas estas ventajas en función de circunstancias locales o coyunturales. Caso, por ejemplo, de Granada, cuyas exenciones finalizaban en 1505, pero que en 1500 recibió una franquicia perpetua en favor de los cristianos que los liberaba del diezmo y medio diezmo de lo morisco y alcabalas sobre las subsistencias, siempre que uno de los contratantes fuese vecino de la ciudad. Posteriormente, también les fueron suprimidas las alcabalas de otros artículos no esenciales. De manera que la mayoría de los repobladores cristianos apenas contribuyeron al fisco en la última década del siglo $\mathrm{XV}$, para facilitar su afluencia y porque se pensaba mantener una alta presión fiscal sobre los musulmanes, como en época nazarí.

Sin embargo, en el siglo XVI, una vez consolidado el territorio, las franquezas perpetuas dadas a Marbella, Vélez-Málaga, Málaga y otras ya no comprendían el almojarifazgo. Salvo en el caso de Almería, que por su menor atractivo recibió ese mismo año de 1501 mayores mercedes; como libertad 
para los vecinos de almojarifazgo, diezmo y medio diezmo de lo morisco de sus labranzas, crianzas y pesquerías si no las vendían a extranjeros, así como de los abastecimientos importados por ellos o gentes foráneas, excepto los intercambiados entre forasteros o los introducidos por mercaderes italianos, siempre que no fuesen reexportados. Mismo caso que el de Almuñécar, según sus privilegios de 1501, 1503 y 1505. En Marbella, el fracaso repoblador llevó a otorgarle en 1515 una redención perpetua de almojarifazgo, de todo lo que allí se cargase o descargase; mientras que la de Mijas afectaba sólo a los productos llevados para abastecimiento de la localidad. En 1550 se siguió un pleito a este respecto entre Sevilla, que finalmente había encabezado el almojarifazgo costero como sabemos, y Marbella, que ganó la primera, en el que la segunda alegó que se pagaba de los productos que entraban por mar y volvían a salir por vía marítima, pero no de los que lo hacían por tierra, o de los metidos y sacados por esa misma ruta. En la sentencia se contiene el privilegio de 1515 que establece la exención a partir de 1520 de los vecinos de sus labranzas y crianzas, pero si las exportaban forasteros debían abonar el impuesto. Del mismo modo, era franca la importación de mantenimientos, siempre que no se vendiesen entre foráneos o se reexportasen, en cuyo caso pagarían el gravamen de entrada y el de salida; que fue lo que a partir del fallo se aplicót0.

Caso similar al de la Andalucía oriental de repoblación de un territorio recientemente conquistado fue el de las Indias. En 1497 los Reyes Católicos eximieron a los productos de ellas provenientes, así como a los que para allá se embarcasen, del pago de derechos, en concreto almojarifazgo, aduana, portazgo, almirantazgo, alcabala de la primera venta y otros. No obstante, como acabamos de ver para las localidades andaluzas, esta merced inicial fue suprimida y acabó por instaurarse el almojarifazgo que se cobraba en las aduanas del Nuevo Mundo. Mientras tanto, como los mercaderes denunciaron que no les era respetada esta franquicia, el rey Fernando emitió en 1505 una cédula en la que la aclaraba, luego confirmada por Juana y Felipe, en 1506; según la cual las mercaderías exportadas e importadas estaban libres del impuesto, pero no así las que entrasen en el arzobispado de Sevilla para ser reexportadas hacia América. Tal y como ocurrió en 1499 con Vicente Yáñez Pinzón, vecino de Palos y descubridor del nuevo continente junto con Colón, quien mani-

40 LÓPEZ DE COCA, 2 (Málaga, 1979): 210-218 y 223. Málaga y su tierra, Mijas, Benalmádena, Fuengirola y Bezmilarana (Rincón de la Victoria), obtuvieron en 1501 franquicia perpetua por el pescado que sus vecinos capturasen y vendiesen en ellas, el exportado sí debía abonar almojarifazgo, AGS, CC, Diversos, 3, 14. Para la franqueza de Almería, AGS, CC, Diversos, 2, 20; para la de Almuñécar, AGS, CC, Diversos, 3, 15. Para el pleito de Marbella, AGS, PR, LC, 5, fols. 308r-329r. En 1506 Juana y Felipe, dada la escasez de cereal que se vivía desde 1503, consintieron introducirlo en el arzobispado de Sevilla y reino de Granada sin pagar almojarifazgo; que se volvió a abonar a partir de 1507, FERNÁNDEZ, OSTOS y PARDO, 1997, vol. 12: 511-513, 530-531, 548-549 y 562-564. 
festó ante el almojarife, Gutierre de Prado, que había sido nombrado capitán por los Reyes Católicos para conquistar estas nuevas tierras, para lo que precisaba sacar de Sevilla armas y pertrechos que solicitaba fuesen exonerados. A lo que el almojarife contestó negativamente a las armas y otros bienes, pues como sabemos eran artículos de reexportación, así como al cargamento que llevaban en los barcos ciertos mercaderes; pero accedió a la salida de 150 tocinos, 20 quintales de aceite, 40 quintales de jarcia, 4 paños bajos de colores, 7 rollos de frisas, 20 lonas para velas y otros suministros para las 4 carabelas que se habían armado, muy probablemente porque habían sido producidos dentro del propio arzobispado de Sevilla. Algo parecido ocurrió en 1516 con 300 varas de jerga que no pagaron nada por ser llevadas a América, pero que fueron requisadas por no abonar almojarifazgo en Sevilla; desde donde, como sabemos, partía y arribaba todo el comercio trasatlántico ${ }^{41}$.

\section{CONCLUSIÓN}

La urgencia repobladora de los territorios andaluces conquistados al Islam entre los siglos XIII y XV, llevó a los monarcas castellanos a conceder generosos privilegios de exoneración de cargas fiscales con los que atraer gentes a las nuevas localidades incorporadas a la Corona. Las mercedes eran directamente proporcionales al grado de inseguridad o atraso de los lugares. De manera que en los casos más extremos casi fueron suprimidos los gravámenes sobre la producción local, el tráfico comercial y el consumo, siempre de manera asimétrica y diferencial en favor de los vecinos que se asentasen en ellos, frente a los mercaderes forasteros que allí traficaban, menos favorecidos. Se trató de una forma de actuar que se dio en diversas regiones de la Europa medieval con escasez de efectivos demográficos y que en Andalucía cobró especial importancia por constituir una región clave para Castilla, por su potencial económico y por ser la puerta de acceso al Atlántico sur, al Mediterráneo y al norte de África. De ahí el gran interés de los reyes por asentar un número creciente de repobladores cristianos y no tener que depender para la explotación de los recursos de la población mudéjar autóctona, siempre peligrosa y sospechosa de confluencia de intereses con la vecina Granada o los musulmanes africanos, potenciales enemigos.

41 AGS, CC, Diversos, 3, 107; 4, 109; 6, 57. AGS, PR, LC, 17, fols. 110v-111r. AGS, Escribanía Mayor de Rentas, 63, fols. 425-426; 100-1; 121-1; 124. AHPS, leg. 3218, fols. 22v-23r. FERNÁNDEZ, OSTOS y PARDO, 1997, vol. 8: 138-142. GOMARIZ, 2006: 16-17. BONO y UNGUETI-BONO, 1986: 430-435. En 1505 Rodrigo de Medina, titular de la cuarta parte del almojarifazgo sevillano, contestó a los oficiales de la Casa de Contratación que no tenían potestad para haber eximido 48 tocinos que tenía retenidos en la casa de la aduana, cuyo destino era América, AHPS, leg. 4886, fol. suelto. 
La forma más fácil en el mundo medieval de atraer inmigrantes a un lugar deshabitado era la del privilegio. Librarlos de las duras obligaciones que pesaban sobre el común de la población en materia impositiva. De manera que, aparte de los pechos e impuestos directos, se prefirió la exención aduanera como merced a los que allí se asentasen para, además de favorecer su instalación, asegurar su futuro crecimiento económico, derivado del tráfico mercantil, de la mayor facilidad de venta de su producción y de la menor tributación por los bienes de consumo y las materias primas.

Sin embargo, estas ventajas iniciales estaban en contradicción con uno de los objetivos principales de la monarquía conquistadora, la obtención de tributos de los habitantes de las nuevas tierras. Por ello, las franquezas fueron recortadas, reducidas e incluso suprimidas cuando las causas que las motivaron remitieron o desaparecieron, y así la presión fiscal aumentó y las promesas reales, algunas de ellas perpetuas, fueron olvidadas o alteradas, incluso por los mismos soberanos que las concedieron.

\section{BIBLIOGRAFÍA}

\section{Fuentes impresas}

Bono y Huerta, José y Ungueti-Bono, Carmen, Los protocolos sevillanos de la época del Descubrimiento. Introducción, catálogo de los protocolos del siglo XV y colección documental, Sevilla, Junta de Decanos de los Colegios notariales de España, 1986.

Fernández Gómez, Marcos, Ostos Salcedo, Pilar y Pardo Rodríguez, María Luisa, El Libro de Privilegios de la ciudad de Sevilla, Sevilla, Ayuntamiento de Sevilla, 1993.

Fernández Gómez, Marcos, Ostos Salcedo, Pilar y Pardo Rodríguez, María Luisa, El Tumbo de los Reyes Católicos del concejo de Sevilla, Madrid, Fundación Ramón Areces, 1997.

García Díaz, Isabel, Documentación medieval del Archivo Municipal de Lorca (1257-1504), Murcia, Universidad de Murcia, 2007.

Gomariz Marín, Antonio, Documentos de Juana I (1505-1510), Murcia, Academia Alfonso X el Sabio, 2006.

González Arce, José Damián, «Ordenanzas y fuero concedidos a la ciudad de Córdoba por Fernando III», Cuadernos de Estudios Medievales, 17 (Granada, 1992): 399-411.

González Arce, José Damián, Documentos de Sevilla en el Archivo Municipal de Murcia. Fueros, Privilegios, Ordenanzas, Cartas, Aranceles (Siglos XIII-XV), Sevilla, Ayuntamiento de Sevilla, 2003.

González Jiménez, Manuel, Catálogo de documentación medieval del Archivo Municipal de Carmona, Sevilla, Diputación de Sevilla, 1976. 
González Jiménez, Manuel, Diplomatario andaluz de Alfonso X, Sevilla, Fundación El Monte, 1991.

Hernández Díaz, José, Sancho Corbacho, Antonio y Collantes de Terán, Francisco, Colección diplomática de Carmona, Sevilla, Editorial de la Gavidia, 1941.

Ordenanças de Sevilla que por sv original... Recopilación de las Ordenanças de la mvy noble y muy leal cibdad de Sevilla..., Sevilla, Otaisa, 1632, edición facsímil de V. Pérez Escolano y F. Villanueva Sandino, Sevilla, 1975.

Rodríguez Molina, José, Colección diplomática del Archivo Histórico Municipal de Jaén, Jaén Ayuntamiento de Jaén, 1985.

\section{Estudios}

Abboud-Haggar, Soha, «Precedentes andalusíes en la fiscalidad de las comunidades mudéjares», En la España Medieval, 31 (Madrid, 2008): 475-512.

Bauduin, Pierre, «Trois cas de peuplement en franchises en Normandie orientale: Villedieu-la-Montagne, Gourchelles, Criquiers (1168-1306)», Histoire \& Sociétés Rurales, 15 (Caen, 2001): 131-164.

Benavides, Antonio, Memorias de don Fernando IV de Castilla, Madrid, Imprenta de José Rodríguez, 1860.

Christiansen, Eric, The Northern Crusades, Londres, Penguin Press, 1997.

Collantes de Terán, Antonio, «Ciudades y villas andaluzas: variedad impositiva y diversidad ante el hecho fiscal», en Finanzas y fiscalidad Municipal, V Congreso de Estudios Medievales, León, Fundación Sánchez Albornoz, 1997: 483-506.

Collantes de Terán, Antonio, «Les impôts municipaux indirects ordinaires et extraordinaires à Séville», en La fiscalité des villes au Moyen Age (Occident méditerranéen). Les systèmes fiscaux, Toulouse, Editions Privat, 1999: 463-483.

Collantes de Terán, Antonio, «La catedral y el almojarifazgo sevillanos en la Baja Edad Media», en Archivos de la Iglesia de Sevilla. Homenaje al archivero don Pedro Marino Rubio, Sevilla, Cajasur, 2006: 125-142.

Collantes de Terán, Antonio, «Los sevillanos ante el impuesto: la exención fiscal (siglos XIII-XVI)», Minervae Baeticae. Boletín de la Real Academia Sevillana de Buenas Letras, $2^{a}$ época/41 (Sevilla, 2013): 293-318.

Collantes de Terán, Antonio, «Fieles, arrendatarios, traspasados y fiadores en las alcabalas de Jerez de la Frontera (1477-1480)», en Entre lo real y lo imaginario. Estudios de Historia Moderna en homenaje al profesor León Carlos Álvarez Santaló, Sevilla, Universidad de Sevilla y Universidad de Huelva, 2014: 141-155.

Epstein, Stephan R., Libertad y crecimiento. El desarrollo de los estados y de los mercados en Europa, 1300-1750, Valencia, Publicacions de la Universitat de València, 2009.

Fernández Hernández, Gonzalo, «El electorado de Brandenburgo, la Orden Teutónica y los orígenes de Prusia», Carthaginensia: Revista de estudios e investigación, 44 (Murcia, 2007): 491-505. 
Font Rius, José María, Cartas de población y franquicia de Cataluña, Madrid, CSIC, 1983.

García Herrero, María del Carmen, «La aduana de Calatayud en el comercio entre Castilla y Aragón a mediados del siglo XV», En la España Medieval, 4 (Madrid, 1984): 363-390.

González Arce, José Damián, «La política fiscal de Alfonso X en el reino de Murcia: portazgo y diezmos», Studia Historica, Historia Medieval, 10 (Salamanca, 1992): 73-100.

González Arce, José Damián, «Las rentas del almojarifazgo de Sevilla», Studia Historica, Historia Medieval, 15 (Salamanca, 1997): 209-254.

González Arce, José Damián, «Producción artesanal y fiscalidad comercial, Murcia ss. XIV-XV», Murgetana, 99 (Murcia, 1999): 93-107.

González Arce, José Damián, «Las rentas del almojarifazgo de Toledo», Anales Toledanos, 61 (Toledo, 2005): 39-70.

González Arce, José Damián, «El consulado genovés de Sevilla (siglos XIII-XV). Aspectos jurisdiccionales, comerciales y fiscales», Studia Historia. Historia Medieval, 28 (Salamanca, 2010): 179-206.

González Arce, José Damián, «El puerto de San Sebastián y su cofradía de mareantes de Santa Catalina», Transportes, Servicios y Telecomunicaciones, 21 (Madrid, 2011): 84-111.

González Arce, José Damián, «De conjunto de rentas a impuesto aduanero. La transformación del almojarifazgo durante el siglo XIV en el reino de Murcia», Anuario de Estudios Medievales, 42/2 (Barcelona, 2012): 669-696.

González Arce, José Damián, «Actividad económica y exacciones fiscales. El almojarifazgo de Jerez en los siglos XIII-XV», en 750 aniversario de la incorporación de Jerez a la Corona de Castilla: 1264-2014, Jerez de la Frontera, Ayuntamiento de Jerez, 2014a: 221-248.

González Arce, José Damián, «La composición de los almojarifazgos señoriales del reino de Sevilla, siglos XIII-XV», Historia. Instituciones. Documentos, 41 (Sevilla, 2014b): 242-273.

González Arce, José Damián, «La evolución del almojarifazgo de Córdoba entre los siglos XIII-XV», En la España Medieval, 37 (Madrid, 2014c): 165-204.

González Arévalo, Raúl, «Comercio exterior del Reino de Sevilla a través de los manuales de mercaderías italianos bajomedievales», Historia. Instituciones. Documentos, 38 (Sevilla, 2011): 219-253.

Gouron, Marcel, Chartes de franchises de Guienne et Gascogne, París, Recueil Sirey, 1935.

Ladero Quesada, Miguel Ángel, «Almojarifazgo sevillano y comercio exterior de Andalucía en el siglo XV», Anuario de Historia Económica y Social, 2 (Madrid, 1969): 69-115.

Ladero Quesada, Miguel Ángel, La Hacienda real de Castilla en el siglo XV, La Laguna, Universidad de La Laguna, 1973a. 
Ladero Quesada, Miguel Ángel, «Las aduanas en Castilla en el siglo XV», Revue internationale d'histoire de la banque, 7 (Ginebra, 1973b): 83-110.

Ladero Quesada, Miguel Ángel, Fiscalidad y poder real en Castilla (1252-1369), Madrid, Universidad Complutense, 1993.

Ladero Quesada, Miguel Ángel, La Hacienda Real de Castilla. 1369-1504, Madrid, Real Academia de la Historia, 2009.

López de Coca Castañer, José Enrique, «Privilegios fiscales y repoblación en el reino de Granada (1485-1520)», Baetica, 2 (Málaga, 1979): 205-223.

Martínez Carrillo, María de los Llanos, «Las aduanas murcianas en el reinado de Enrique II», en Homenaje al profesor Juan Torres Fontes, 2, Murcia, Universidad de Murcia, 1987: 987-1.004.

Menjot, Denis, «La fiscalité douanière dans le royaume de Murcie», en L'argent au Moyen Age. XXVIIIe. Congrès de la Société des Médiévistes de l'Enseignement Supérieur, París, Universidad de la Sorbona, 1987: 209-234.

Ortuño Molina, Jorge, «La aduana del puerto de Yecla como fuente de rentas», Yakka, 8 (Yecla, 1997): 187-193.

Porras Arboledas, Pedro A., «Los portazgos en León y Castilla durante la Edad Media. Política real y circuitos comerciales», En la España Medieval, 15 (Madrid, 1992): 161-211.

Rojas Gabriel, Manuel, Olvera en la baja Edad Media (siglos XIV-XVI), Cádiz, Diputación de Cádiz, 1987.

Romero Medina, Raúl, «Almojarifazgo portuense (1489-1541)», Revista de Historia de El Puerto, 42 (El Puerto de Santa María, 2009): 35-62.

Recibido: $14 / 01 / 2016$

Aprobado: 26/10/2016 